\title{
Pediatric eosinophilic esophagitis: a review for the clinician
}

\author{
Simona Barni ${ }^{1}$, Stefania Arasi ${ }^{2}$, Carla Mastrorilli, ${ }^{3,4}$, Luca Pecoraro ${ }^{5,6}$, Mattia Giovannini ${ }^{1 *}$ (D), Francesca Mori ${ }^{1}$, \\ Lucia Liotti ${ }^{7}$, Francesca Saretta ${ }^{8}$, Riccardo Castagnoli ${ }^{9}$, Lucia Caminiti ${ }^{10}$, Antonella Cianferoni ${ }^{11,12+}$ and \\ Elio Novembre ${ }^{1+}$
}

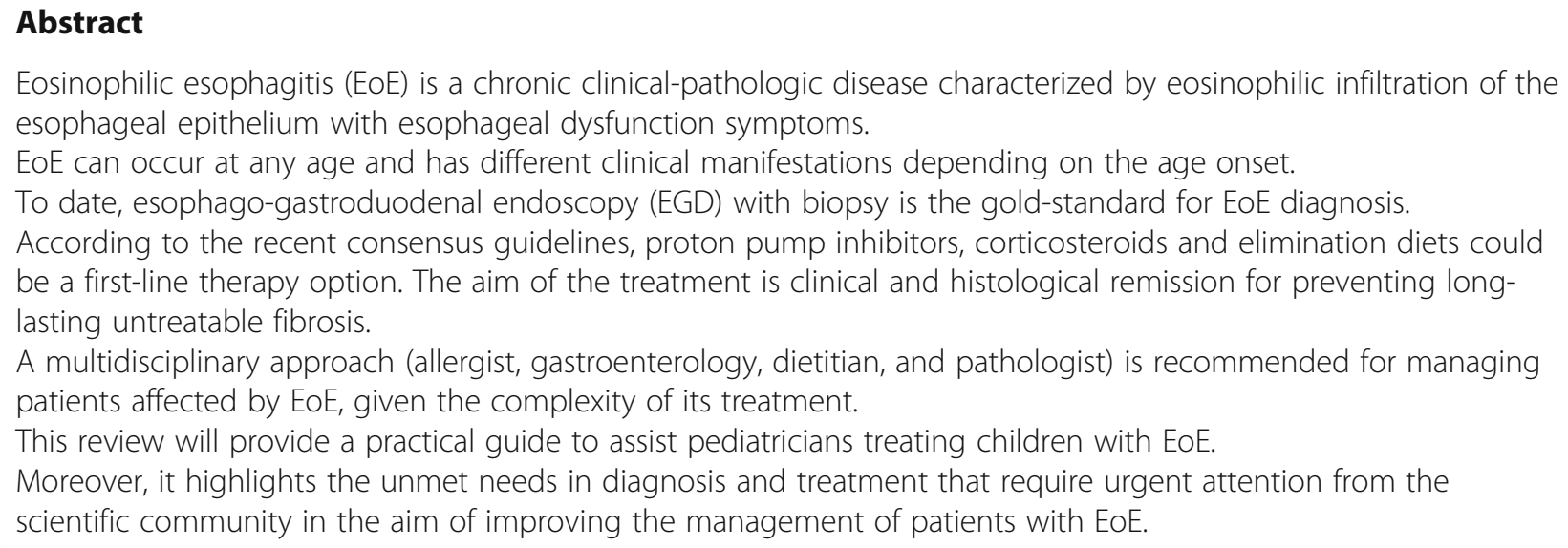

\section{Introduction}

Eosinophilic esophagitis (EoE) is a chronic immunemediated disease characterized by clinical manifestations related to esophageal dysfunction and, histologically, by esophageal eosinophilic inflammation [1].

In recent decades, the incidence and prevalence of EoE has increased [2-4], being the leading cause of dysphagia in children and young adults [5]. Currently, esophageal biopsy through upper gastrointestinal endoscopy still remains the gold standard diagnostic test to perform when EoE is suspected [1]. Since upper endoscopy is an invasive and expensive procedure, less invasive tools are being developed to evaluate esophagus inflammation, however, larger studies are needed to validate these tests [6-12].

\footnotetext{
* Correspondence: mattiag88@hotmail.it

${ }^{+}$Antonella Cianferoni and Elio Novembre are joint last co-authors.

${ }^{1}$ Allergy Unit, Department of Pediatrics, Meyer Children's University Hospital, Florence, Italy

Full list of author information is available at the end of the article
}

According to the last consensus guidelines, proton pump inhibitors (PPIs) are considered first-line therapeutic options on the same level as steroids and elimination diet [1]. The treatment must be individualized according to each patient's lifestyle and family situation and could be interchangeable over time [13].

The aim of this review is to update the current evidence on EoE in children, moreover, it is intended as a practical guide for clinicians treating patients with EoE in order to avoid delayed diagnosis which can lead to inflammatory progression and ultimately, fibrostenosis [14].

\section{Research strategies and literature analysis}

We reviewed the most relevant studies on "Pediatric Eosinophilic Esophagitis" present in databases including PubMed (https://www.ncbi.nlm.nih.gov/pubmed/) and the Cochrane Library up until 2020. Manuscripts were selected from randomized controlled trials, case reports, 
reviews, systematic reviews, cohort and case-control studies, and observational studies. Single-case reports, abstracts/posters without sufficient detail, articles with duplicated data, and articles in non-English language were all excluded. The terms searched for were "pediatric eosinophilic esophagitis" [all fields]; "eosinophilic esophagitis" and "children" [all fields]; "pediatric eosinophilic esophagitis" and "management" [all fields]; "pediatric eosinophilic esophagitis" and "treatment" [all fields]; "pediatric eosinophilic esophagitis" and "therapy" [all fields]; "pediatric eosinophilic esophagitis" and "diet" [all fields]; "esophageal eosinophilia" [all fields]; "pediatric GERD" [all fields]; "gastroesophageal reflux" and "children" [all fields].

\section{Epidemiology}

EoE has been characterized as a disease relatively recently, with the first description by Landres et al. in 1978 [15]. Over time, EoE has gained more and more interest and, in parallel, the epidemiology of EoE has also rapidly increased, in particular after the publication of the consensus recommendations for diagnosis and management of the disease in 2007 [16]. However, the increase in recognition and knowledge of EoE would not seem to be the only explanation for such a rise in frequency [1]. This observation might entail implications for the knowledge of the etiology of EoE which has transformed from a rare case-reportable condition into a major cause of food impaction and the leading cause of dysphagia in children and young adults [5].

Most data come from population-based studies, conducted primarily in North America and Europe [2, $3,17-21]$. Incidence rates range from 2.1/100,000/ year in the Netherlands [4] to $12.8 / 100,000 /$ year in Ohio in the United States [22]. In 2016, a metaanalysis evaluated the epidemiology of EoE reported by various countries and calculated an overall pooled incidence of 3.7/100,000/year (95\% confidence interval [CI], 1.7-6.5) which was higher in adults $(7 / 100,000 /$ year; 95\% CI:1-18.3) than in children (5/100,000/year; 95\% CI: 1.5-10.9). The same study assessed an overall prevalence of 22.7 cases per 100,000 inhabitants, being the highest in North America with a prevalence of 30.7 cases per 100,000 inhabitants, despite substantial heterogeneity [23].

However, when interpreting the published epidemiology data, it is important to recognize heterogeneities among studies performed at different centers and during different periods. The reported frequency varied widely, probably due to differences in multiple factors such as clinical and laboratory criteria, patients' ages, duration of illness, and geographic variations in dietary habits. Further data from well-designed homogeneous studies are necessary.

\section{Pathogenesis}

EoE is characterized by a multifactorial esophageal inflammation occurring in individuals with genetic predisposition, which combines an esophageal epithelia dysfunction and an abnormal T-helper cell type 2 (Th2)mediated immune response to environmental allergens, and leads to esophageal lesion and dysmotility, secondary remodeling and fibrosis [24-26].

\section{Genetic factors}

The risk of developing EoE is higher among first-degree family members, in particular, being a father or a brother of a patients affected by EoE, increases the risk of developing the disease 43-fold and 64-fold respectively, whereas the EoE frequency exhibited in monozygotic and dizygotic twins is 41 and $22 \%$ respectively [7].

Multiple genome-wide association studies (GWAS) have been conducted to identify genetic loci associated with EoE $[27,28]$. Some of the genes have known functions, while others are still unknown [28]. Most of the genetic loci identified affect epithelial barrier functions and Th2-mediated immune responses [29, 30].

The thymic stromal lymphopoietin (TSLP) gene has been associated with EoE in multiple independent studies. TSLP is an epithelial cytokine that favors a pro-Th2 environment [27, 31, 32]. However other genes have emerged in the EoE pathogenesis that are located in the epidermal differentiation complex (1q21), several of which are dysregulated and involved in epithelial cell differentiation [33].

Desmoglein-1 (DSG1), downregulated by interleukin (IL)-13, gives rise to an epithelial cell barrier disfunction [31].

Calpain-14 (CALPN14), an esophagus-specific proteolytic enzyme induced by IL-13, leads to a loss of DSG1 expression and impaired epithelial barrier function [34]. Moreover, filaggrin (FLG), a fundamental epithelial protein, is downregulated in EoE [30].

Lastly, the serine peptidase inhibitor Kazal type 5 and 7 (SPINK5 and SPINK7) participates in EoE pathogenesis because the activity of serine proteases is not under control [30].

As a result, increased esophageal tissue permeability and antigen uptake could give rise to an abnormal Th2immune response. This involves several cytokines such as IL-4, IL-5 and IL-13 [24, 25]. IL-4, secreted by Th2 cells, natural killer (NK) cells, and basophils, which induce the differentiation of $\mathrm{T}$ cell into Th2 and active $\mathrm{B}$ cells $[25,35]$. IL-5, secreted by Th2 cells, mast cells, and eosinophils, promotes eosinophil proliferation, survival, activation, and chemotaxis [36-38].

In addition to the effects mentioned above, IL-13, secreted by Th2 cells, upregulates eotaxin-3 (CCL26) that causes chemotaxis of the eosinophils [33]. Moreover, IL- 
13 upregulates periostin (POSTN) and transforms the growth factor (TGF)- $\beta$, increasing the adhesion of the eosinophils to fibronectin [39]. Furthermore, TGF- $\beta$ directly induces the expression of profibrotic genes, such as fibronectin, collagen I, periostin, and smooth muscle actin, causing esophageal epithelial fibrosis and decreasing esophageal smooth-muscle contraction [40, 41].

Ultimately, IL-13 induces tissue remodeling by promoting collagen deposition, angiogenesis, and epithelial hyperplasia [37, 42].

A close relationship between DSG1 and POSTN highlights the interaction between epithelial barrier dysfunction and the Th2-mediated immune response: when DSG1 is downregulated, POSTN increases, triggering the production of TSLP by the esophageal epithelium. TSLP induces a Th2-immune response and is implicated in eosinophil survival, and mast cell and basophil activation [40, 43-45].

STAT6 (12q13), which is associated with the pathogenesis of EoE. is activated by IL- 4 and IL-13 and encodes for a transcription factor activating many EoE genes $[29,30]$.

\section{Environmental factors}

The rapid increase in the incidence and prevalence of EoE demonstrates the paramount role of environmental factors in its pathogenesis $[24,26,46]$. The exposure to environmental allergens can also play a critical role in developing the disease and its exacerbation, such as the pollen season, Fall, or living in a cold or dry climate [24].

Moreover, living in a rural environment increases the risk of developing EoE because of increased exposure to aeroallergens [47]. Furthermore, animal models support a link between antigen exposure and EoE [48]. Specifically, a mice model of experimental esophagitis induced by exposing to a respiratory allergen (Aspergillus fumigatus and dust mite mixture) was developed by Mishra et al. [49]. Mice exposed to the allergen revealed an increase in esophageal eosinophils, free eosinophil granules, and epithelial cell hyperplasia [49].

Atopy is present in $75 \%$ of patients with EoE [50]; in particular, it has been demonstrated that a history of atopic dermatitis (AD), IgE-mediated food allergy, and asthma are independently and cumulatively associated with the diagnosis of EoE [51]. In addition, children affected by IgE-mediated food allergy, especially those with multiple food allergies, can develop EoE at 9 times the rate of children without this disorder [52]. Similarly, the risk of EoE development in patients suffering from IgE-mediated food allergy who are on oral immunotherapy increases to 2.7-5.3\% [53]. Additionally, an association between EoE, asthma and airway hyperresponsiveness (AHR) has been highlighted [54]: a cross-sectional prospective study demonstrated that AHR is more frequent in subjects affected by EoE than in the control group (33\% vs. $11 \%$ ) and a high level of s-IgE in these patients is associated with a greater risk of AHR.

Early-life environmental exposures play a role too: maternal fever, pre-and postnatal antibiotics, proton pomp inhibitor (PPI) therapy, and neonatal intensive care unit admission in early life are associated with an increased risk of EoE $[26,55]$. The theory is that early exposure could alter gut microbiota, which in turn may alter the development of the normal immune system [56].

On the other hand, Helicobacter pylori (H. pylori) seems to have a protective effect on esophageal eosinophilia [57]. This evidence could be explained by the fact that H. pylori may drive a Th1 mediated allergic response, shifting the Th1-Th2 balance and protecting from an allergic Th2 response [58]. An overview of EoE pathogenesis is shown in Fig. 1.

\section{Clinical manifestations}

EoE is characterized by different clinical manifestations according to different ages of onset [60, 61]. Infants present with food refusal, failure to thrive and gastroesophageal reflux; school-aged children present with symptoms of gastroesophageal reflux and finally, adolescents and adults presents with dysphagia and food impaction. Clinical manifestation of EoE in infancy, childhood and adolescence/adulthood is indicated in Fig. 2.

These differences in clinical onset is postulated to derive from different causes: first of all, infants and children fail to express their symptoms in the same manner as adolescents and adults, secondly, the esophageal tissue remodeling is progressive and develops over time from an inflammatory phenotype in childhood to a fibrostenotic phenotype in adulthood [14, 63-65].

Moreover, the symptoms could be masked, because the patients may have adapted compensatory feeding habits (eating slowly, excessive mastication, cutting food into small pieces) and dietary changes (preference for liquids and soft food, and avoidance of specific textures like meat and bread) to prevent the development of symptoms (dysphagia and food impaction) $[58,60,62,66,67]$.

Therefore, it is of paramount importance to include the following questions in the medical history: "Do you chew your food a lot?" "Are you the last to get up from the table?" "Do you drink plenty of water during the meal to help you swallow?" "Do you avoid eating certain foods such as bread, rice, or meat?" "Do you cut the food into very small pieces?" $[60,68]$.

Since EoE symptoms are unspecific, especially in infants and children, diagnosis is reached with an average delay of 3-5 years $[69,70]$, with an increasing risk of developing fibrosis [70]. Indeed, the risk of fibrostenosis 


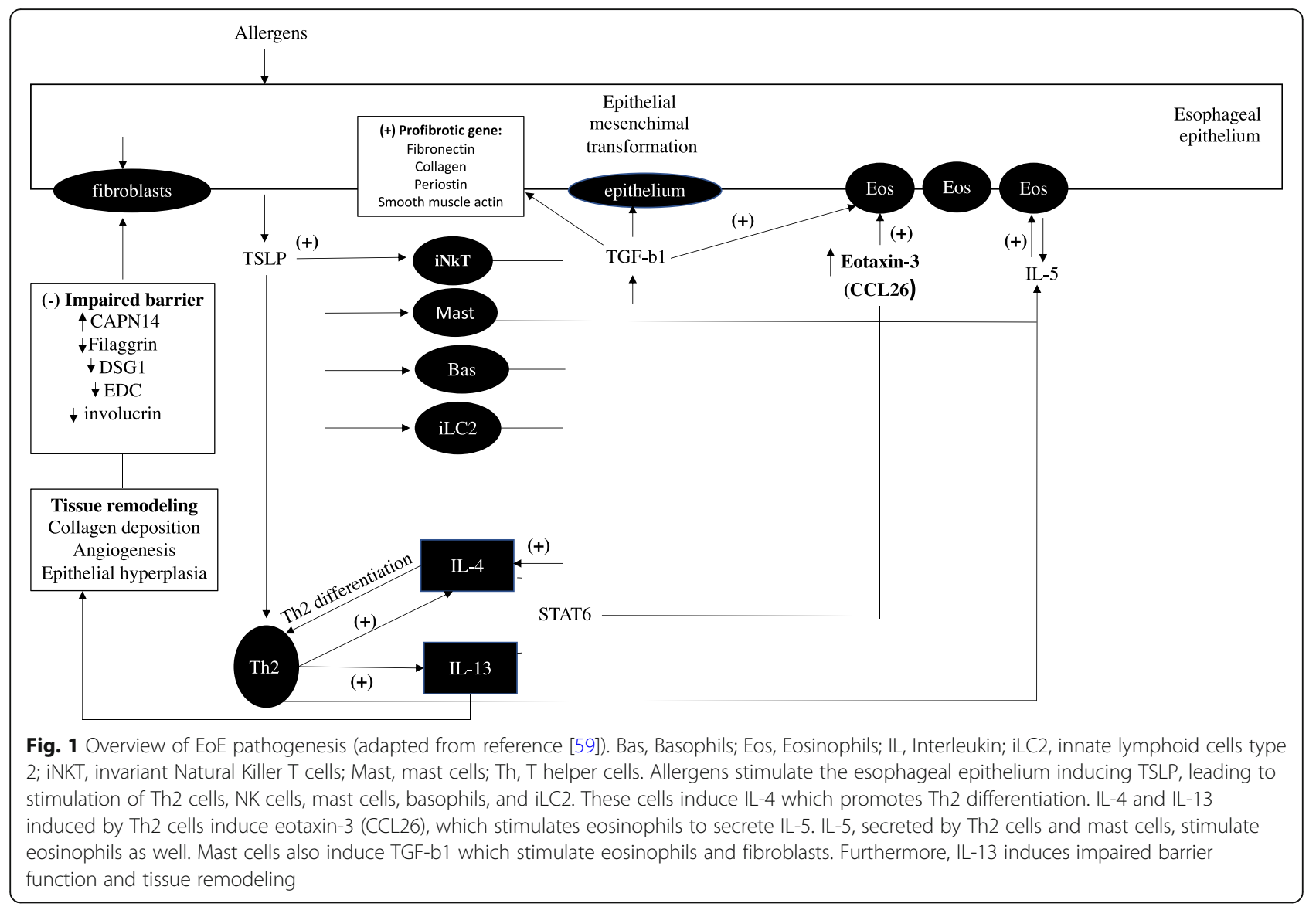

increases by $5 \%$ with each year of symptoms before diagnosis [70].

Extraesophageal symptoms could be associated with EoE as reported for the first time by Orenstein et al. [71]. It is unclear whether the respiratory symptoms were caused by EoE or whether the relationship was due to allergic conditions coexisting in a cohort of children having a common atopic background [72]. There are a lot of theories on this subject: first of all, the hypothesis that explains the onset of respiratory symptoms due to the generating of proinflammatory cytokines by the eosinophils living in the upper esophagus [73-75]. Alternatively, other authors have hypothesized the role of micro-aspiration, resulting in food antigens gaining direct access to the immune system via the lungs while circumventing the gastrointestinal tract [71]. According to this hypothesis, the interaction of food antigens directly with the immune system causes the development of an

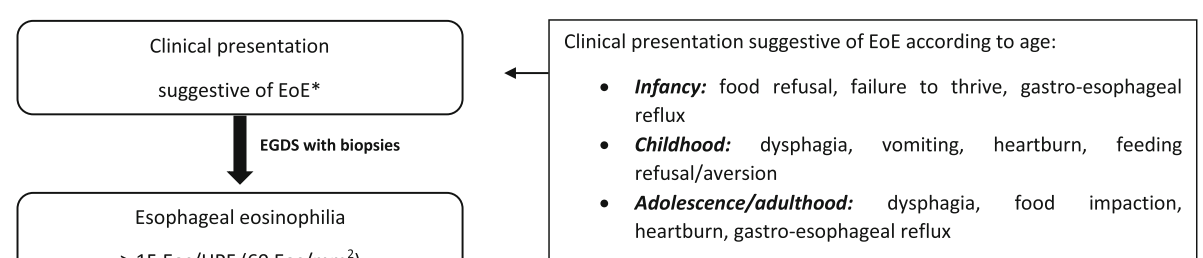

$15 \mathrm{Eos} / \mathrm{HPF}\left(60 \mathrm{Eos} / \mathrm{mm}^{2}\right.$ )

GERD, parasitic and fungal infections, Crohn's disease, esophageal

Differential diagnosis with other causes of esophageal eosinophilia versus-host disease

Eosinophilic esophagitis

Fig. 2 Clinical manifestation and diagnostic algorithm for eosinophilic esophagitis (Modified from reference [62]). EGD,

esophagogastroduodenoscopy; EoE, Eosinophilic Esophagitis; Eos, Eosinophils; GERD, gastroesophageal reflux disease; HPF, high-power field 
allergic response and subsequently, EoE [71]. However, several studies are necessary to understand in detail the interrelationship between esophageal and respiratory symptoms in patients affected by EoE [72].

EoE is strongly associated with some comorbidities, such as atopic conditions, and therefore these patients should be screened routinely for EoE [51]. In particular, 26-50\% of EoE patients have concomitant asthma, 3090\% have associated allergic rhinitis, $19-55 \%$ have atopic dermatitis and, 9.8-68\% have IgE-mediated food allergy [52, 76-80]. Moreover, other non-atopic diseases have been shown to be associated with EoE, such as inflammatory bowel disease [81] connective tissue disorders [82], autism [83], attention deficit hyperactivity disorder [83], celiac disease $[83,84]$ and other monogenic disorders $[83,85]$. This group of patients may be overrepresented in 21-25\% cases by those who do not demonstrate concomitant allergic disease [78], as they could be represented by a different EoE-phenotype [86].

When EoE is suspected based on symptoms, the EGD with biopsy is the only way to confirm the diagnosis $[1,61]$.

\section{Diagnosis}

The diagnosis of EoE has undergone several updates in the last two decades with the birth of new concepts and evidence $[16,69,87,88]$. In 2018, an international consensus [1] based on a systematic review of literature and expert opinions revised the EoE diagnostic criteria. It defined EoE as a clinicopathologic disease characterized by [1] esophageal symptoms, e.g., dysphagia and food impaction in adults, and feeding intolerance and gastroesophageal reflux disease (GERD) symptoms in children, together with [2] eosinophil-predominant inflammation of 15 or more eosinophils per high-power field (hpf) (i.e., $\geq 15$ eos/hpf) in the esophageal tissue [3] after exclusion of other disorders associated with similar clinical, histologic, or endoscopic features [1]. The diagnostic algorithm for EoE is illustrated in Fig. 2 [62].

The main novelty introduced by the recent consensus guidelines is the removal of failed twice-daily or highdose proton pump inhibitor (PPI) therapy before diagnosing EoE. This derives from the evidence that although PPIs primarily provide acid blockade, they can also have anti-inflammatory effects (e.g., decrease of IL13-induced eotaxin-3 production) [89, 90]. Currently, PPI-responsive esophageal eosinophilia (PPI-REE) is considered an EoE sub-phenotype, since it does not differ from EoE in clinical, endoscopic or histological characteristics and, therefore, PPI is considered a therapeutic option for EoE on the same level as diets and topical steroid treatment, and as such, is no longer a diagnostic criterion [1].
The gold standard for EoE diagnosis is still biopsy findings that demonstrate increased intraepithelial esophageal eosinophil counts without concomitant eosinophilic infiltration in the stomach or duodenum [16]. Since eosinophilic infiltration of the esophagus might be patchy (i.e., non-continuously distributed), at least five biopsy specimens should be obtained at multiple levels from the proximal and distal esophagus to maximize sensitivity, targeting mainly areas of apparent inflammation. Together with the key diagnostic criterion of esophageal eosinophilia (i.e., $\geq 15$ eos/hpf), other histologic features of EoE include superficial layering of the eosinophils, eosinophilic micro-abscesses (clusters of $>4$ eosinophils), basal zone hyperplasia, dilated intercellular spaces, surface epithelial alteration, dyskeratotic epithelial cells, and lamina propria fibrosis. Some patients with EoE, adults and children alike, may present subepithelial fibrosis in their biopsy specimens [91, 92]. Based on current knowledge, a newer EoE histologic severity scoring index has been developed, called the EoE histologic scoring system (EoEHSS) [93], which does not focus solely on eosinophil numbers but also takes the abovementioned histologic features into account [93].

Although the histologic feature of eosinophilia is the key factor for a diagnosis of EoE, it is not pathognomonic of EoE [1]. Therefore, to formulate a proper diagnosis, it is essential to investigate any secondary causes of esophageal eosinophilia. The differential diagnosis for EoE is broad and can include GERD, parasitic and fungal infections, Crohn's disease, allergic vasculitis, connective tissue disease, and other disorders associated with esophageal eosinophilia [1]. For an accurate diagnosis and management, it is important to treat the potential primary disease and evaluate whether this induces the remission of esophageal eosinophilia. If still present, then a diagnosis of concurrent EoE is formulated. Often it is not initially possible to make a distinction between EoE and GERD as the symptoms of these 2 diseases overlap [94]. However, if symptoms fail to improve with PPIs or if they recur shortly after PPI suspension, an esophago-gastro-duodenoscopy (EGD) is recommended to detect eosinophilic infiltration. If more than 15 eos/ hpf are found, the diagnosis of EoE is made even if there are typical reflux symptoms [1].

Furthermore, it is recommended to assess whether any iatrogenic EoE triggers (e.g., oral immunotherapy, OIT) exist. Specifically, a minority of patients (2.7 to $5.7 \%$ ) undergoing OIT for the treatment of food induced anaphylaxis are at risk of EoE [53, 95]. If patients develop EoE during OIT, they are advised to discontinue the therapy, usually with an improvement in the clinical and histological EoE manifestations. Even though cases of sublingual immunotherapy inducing EoE have been reported, they are rare [96-98]. 


\section{Less invasive techniques to evaluate the esophagus}

Researchers have focused on the development of less invasive tools to evaluate esophagus inflammation, since upper endoscopy is an invasive and expensive procedure, even requiring general anesthesia in children and conscious sedation in most adult patients. Moreover, in 2016, the Food and Drug Administration issued a safety warning states that "repeated or lengthy use of general anesthetic and sedation drugs during surgeries or procedures in children younger than 3 years or in pregnant women during their third trimester may affect the development of children's brains", caused increase concerns over anesthetic exposure at a young age leading to anesthetic-induced neurotoxicity $[99,100]$. Since then, more caution has been used to do repeated EGD under anesthesia.

Un-sedated transnasal endoscopy has been used in children and adults to assess esophageal mucosal inflammation through biopsy [6].

Although radiography is not useful in identifying the inflammatory findings of edema and exudates, it can be helpful in evaluating fibrostenotic disease [7, 8]. Barium esophagography is more sensitive than endoscopy for detecting esophageal stricture and diffuse small-caliber esophagus [9].

An instrumental examination currently being validated is the esophageal string-test (EST). Consisting of a nylon thread the distal end of which is attached to a gelatin capsule that captures eosinophil-associated proteins from the esophageal lumen, it has shown good correlation with eosinophilic infiltration in esophageal biopsy specimens in both children and adults [10]. Another capsule-based technology is the Cytosponge (Medtronic, Minneapolis, Minn); originally designed for assessment of the esophageal mucosa in patients with Barrett's esophagus, it has recently been used to assess inflammation in adult patients with EoE [11].

A tethered confocal microscopy capsule has been piloted in adults with EoE, with preliminary results suggesting that comprehensive cellular data can be gathered for assessing tissue inflammation [12]. All these methods are promising for assessing inflammation without the use of standard endoscopy. Although they are unlikely to replace the diagnostic or therapeutic benefits of endoscopy when a diagnosis or dilation is needed, they could play an important role in replacing repeated endoscopies for disease surveillance after treatment interventions.

Other non-invasive biomarkers are also under investigation for reducing the need for repeated endoscopies and biopsies which entail significant costs, risks, and discomfort for patients, [101]. Several candidates have been studied, mainly in the blood/serum, but also in the urine, stools and breath testing [101]. The composition of the salivary microbiome community structure has been shown to be altered in children with EoE [102, 103].

Fractionated exhaled nitric oxide testing (FeNO) is a standardized non-invasive test with proven utility in the evaluation of asthma. The use of elevated FeNO has also been reported in other eosinophilic inflammatory conditions. However, in eosinophilic esophagitis, FeNO has limited clinical efficacy in predicting severity of esophageal eosinophilia. A study conducted in 50 patients with EoE has shown that in patients with FeNO levels $>40$ $\mathrm{ppb}$, specificity of testing was high, but very few patients reached this FeNO level [104].

\section{Emerging diagnostic tools}

Thickening of the deeper layers of the esophagus has been demonstrated via use of endoscopic ultrasonography $[105,106]$. The endoscopic functional luminal imaging probe (endoFLIP) is a new technique for assessing mucosal and submucosal fibrosis and smooth-muscle hypertrophy which are likely to cause decreased esophageal compliance, contributing to dysphagia symptoms in the absence of an identifiable stricture [107]. A balloon mucosal impedance (MI) catheter system that instantly detects changes in esophageal mucosal integrity during endoscopy over a long segment of the esophagus during endoscopy has been found to be safe and reliable in identifying patients with GERD, EoE, or non-GERD [108]. Furthermore, endoscopic mucosal impedance measurements correlate with eosinophilia and dilation of intercellular spaces in patients with EoE, adults and children alike [11, 109].

While histologic assessment is the gold standard in diagnosing EoE, in those patients with a high pre-test probability of EoE and eosinophil count $<15 \mathrm{hpf}$, tissue staining for eosinophil products, such as eosinophil peroxidase (EPX), might be useful, even though EPX staining remains a research tool [110].

Furthermore, the eosinophilic esophagitis diagnostic panel (EDP) is a molecular tool which assesses the expression of 96 genes that are dysregulated in patients with EoE and has high sensitivity and specificity for diagnosis and molecular phenotyping in EoE [111]. In this regard, a multicenter cross-sectional study analyzed 185 esophageal biopsy specimens from pediatric and adult patients with EoE, using EDP. Histological and endoscopic features were assessed by quantification of esophageal eosinophils and via use of the eosinophilic esophagitis histology scoring system (EoEHSS) and the eosinophilic esophagitis endoscopic reference score (EREFS). In a validation cohort consisting of 100 specimens, the EDP identified three clusters significantly associated with distinct endotypes (termed EoEe1-3) despite similar eosinophil levels. EoEe1 was associated with a normal-appearing esophagus (risk ratio [RR] 3.7, 95\% CI 1.04-10.27; $p=0.0443$ ), an inverse 
association with a history of esophageal dilation (0.27, $0.09-0.82 ; p=0.0105$ ), and relatively mild histological, endoscopic, and molecular changes. EoEe2 showed an inflammatory and steroid-refractory phenotype (RR 2.77, 95\% CI 1.11-6.95; $p=0.0376)$ and had the highest expression of inflammatory cytokines and steroid-responding genes. EoEe3, which was associated with a narrow-caliber esophagus (RR 7.98, 95\% CI 1.84-34.64; $p=0.0013$ ) and adult onset $(2.22,1.19-4.12 ; p=0.0155)$, showed the highest degree of endoscopic and histological severity and the lowest expression of epithelial differentiation genes. It has been speculated that this classification might have potential clinical and therapeutic significance in the perspective of a precision-medicine approach to EoE [31].

\section{Therapy}

The aims of EoE therapy include the accomplishment of clinical and histological remission in order to prevent long-lasting untreatable fibrosis [63-65].

As the therapy is likely to be lifelong, the prevention of iatrogenic impairment triggered by adverse events of pharmacological treatments and long-standing elimination diets is crucial [112]. The clinical practice algorithm for the management of pediatric eosinophilic esophagitis is illustrated in Fig. 3.

\section{Acid suppression}

According to the recent consensus guidelines [1], PPIs can be chosen as a first-line treatment option like steroids and elimination diets, since updated diagnostic criteria $[1,113]$ indicate that a failed PPI trial prior to endoscopy is not necessary for making a diagnosis of EoE. Given the simplicity of administration and lack of significant side effects, they are often the first choice [69, $116,117]$, especially among patients with milder symptoms, low inflammation, and low levels of fibrosis [111]. They are used at high dosages (e.g., 40-mg omeprazole is administered twice a day or $1-2 \mathrm{mg} / \mathrm{kg}$ in children), probably to exploit their anti-inflammatory properties $[89,90]$. An EGD needs to be repeated to prove its efficacy as often symptoms that improve with PPI treatment may still be associated with profibrotic esophageal inflammation requiring a step-up treatment [116]. PPI are considered safe drug, nevertheless possible recognized side effects of long-term acid suppression are dysbiosis, malabsorption, osteoporosis, and possible higher risk for gastrointestinal and respiratory infections $[118,119]$.

The first-line options for pediatric EoE treatment are summarized in Table 1.

\section{Dietary modifications}

Elimination of allergens and antigens from diet addresses the removal of the causes of inflammation and should consider the patients' lifestyle, adherence aptitude, and family resources [67, 120, 121]. While popular a few years ago, they are now used less frequently as more pharmacological options become available [121]. Several dietary strategies have been developed: 1) the targeted elimination diet (TED), based on allergy testing in order to recognize potential allergens and eliminate

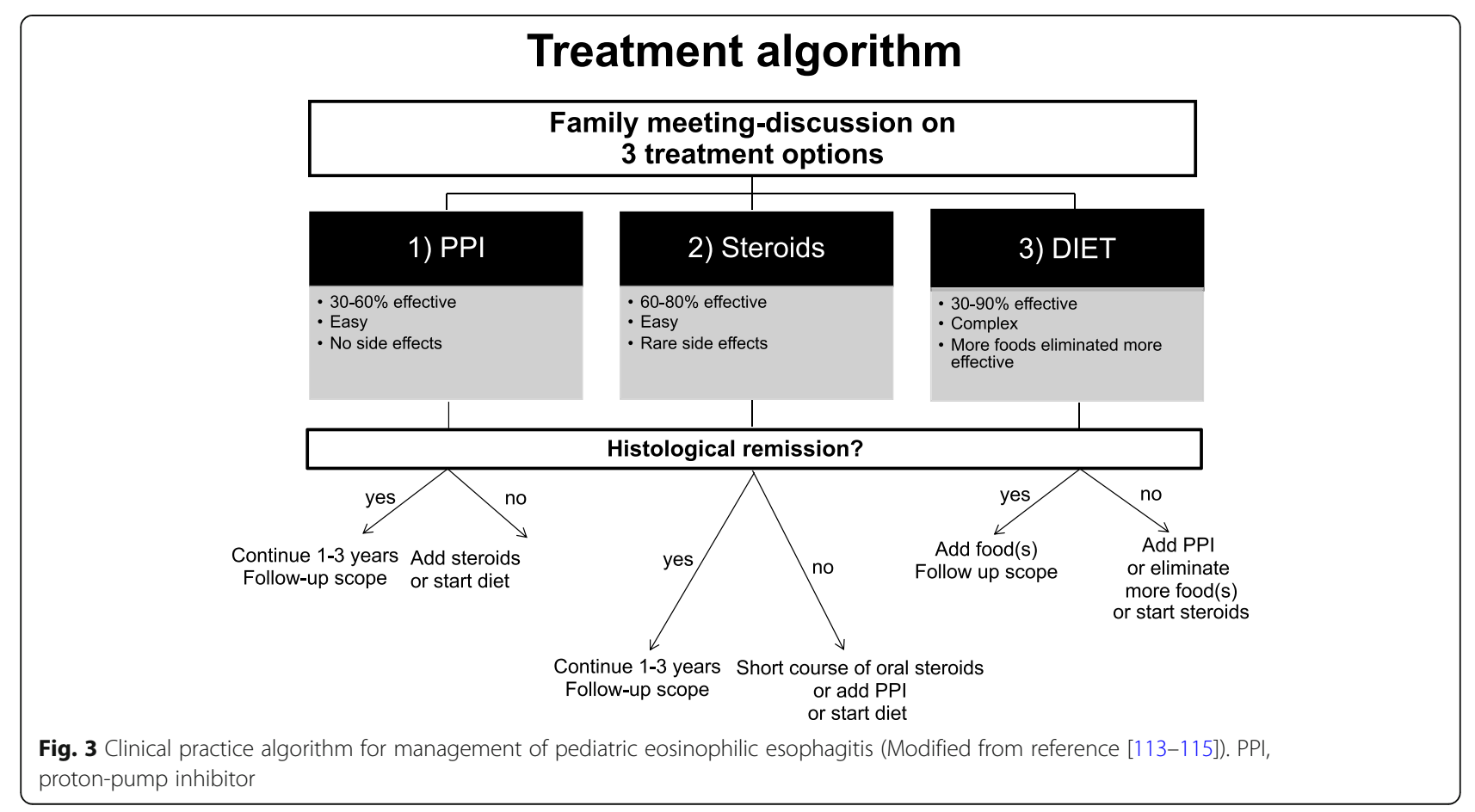


Table 1 First-line therapies in pediatric eosinophilic esophagitis

\begin{tabular}{|c|c|}
\hline Drug & Daily induction dosing (usually divided doses) \\
\hline \multicolumn{2}{|l|}{ Proton pump inhibitors } \\
\hline Omeprazole & 1 mg/kg BID (max 20-40 mg) \\
\hline Lansoprazole & 1 mg/kg BID (max 60 mg) \\
\hline Esomeprazole & $1 \mathrm{mg} / \mathrm{kg}$ QD (max $40 \mathrm{mg})$ \\
\hline Pantoprazole & $\begin{array}{l}<10 \text { years of age: } 1 \mathrm{mg} / \mathrm{kg} \text { QD }(\max 40 \mathrm{mg}) \\
>10 \text { years of age: } 20 \mathrm{mg} \mathrm{QD}(\max 40 \mathrm{mg})\end{array}$ \\
\hline \multicolumn{2}{|l|}{ Topical steroids } \\
\hline Swallowed, inhaled fluticasone propionate ${ }^{a}$ & 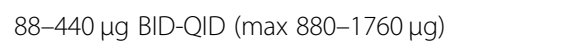 \\
\hline Oral viscous budesonide ${ }^{b}$ & $\begin{array}{l}<10 \text { years of age: } 0.5 \mathrm{mg} \mathrm{BID}(\max 4 \mathrm{mg}) \\
>10 \text { years of age: } 1 \mathrm{mg} \operatorname{BID}(\max 4 \mathrm{mg})\end{array}$ \\
\hline \multicolumn{2}{|l|}{ Systemic steroids } \\
\hline Prednisone & $1-2 \mathrm{mg} / \mathrm{kg} B \mathrm{BI}(\max 30 \mathrm{mg} B I D)$ \\
\hline
\end{tabular}

them from the diet; 2) the empiric elimination diet (EED) or six-food elimination diet (SFED) that removes the most frequent foods causing allergic reactions (e.g. the "big six": cow's milk, egg, soy, wheat, peanuts/tree nuts, and fish/shellfish); 3) the elemental diet (ED) that avoids all potential allergenic food proteins altogether. After the establishment of a histologic disease activity resolution, excluded foods should be reintroduced separately to achieve a less restrictive and more effective diet. Elimination diets suggest an overall success rate that varies between 45 and $90 \%$ depending on the different approaches. In particular, the ED resulted in a histologic response of approximately $90 \%$ in meta-analysis, but with high patient nonadherence and dropout because of low palatability [122-124]. According to the recent guidelines [1], an ED should only be used for 4 weeks as a last resort in highly refractory cases followed by an EGD to show resolution, and the fast reintroduction of foods should be recommended [121]. In fact, while ED can be useful and has an efficacy rate of at least $90 \%$ in children affected by multiple food allergies, growth deficiency, refractory disease, and highly unbalanced diets, in older children it almost always requires nasogastric tube feeding due to its unpleasant taste and it can mask a feeding disorder, especially in malnourished patients [125-127].

Empiric elimination in these diets can be performed with a step-up approach, starting with the elimination of the most common triggers ( 1 or 2 foods, such as wheat and milk) and progressively excluding other foods until histologic resolution is achieved with an endoscopy. Otherwise, a step-down approach can be applied, starting with a highly restrictive diet (the most commonly used is SFED) and progressing with gradual food introduction. Although SFED has been well analyzed in the treatment of EoE, with histologic remission in $72 \%$ of children and $65-70 \%$ with a 1-2 food elimination diet, the latter seem to have better long-term compliance with fewer endoscopies so it is generally preferred [121, $122,128,129]$. Endoscopy is performed 6-12 weeks after dietary variations to evaluate histologic disease activity. TD has been less popular in the last few years since IgE testing does not predict food allergy triggers in EoE and path testing is scarcely specific or sensitive and it is not standardized. Indeed, the success rate of TD is lower than SFED [50, 121, 130].

The different elimination diets are summarized in Table 2.

The major detriments of dietary elimination in children are nutritional deficiency, decreased quality of life, psychological impact and the risk of developing feeding disorders (e.g anorexia and bulimia, especially in adolescents) [112].

\section{Steroids}

Due to being highly successful in patients with EoE, topical corticosteroids are often used as first-line treatment in more severe cases or in those that fail with PPIs. They induce clinical and histological remission, consistently prevent fibrosis and require fewer endoscopies, hence they are often preferred over diet treatment. While systemic steroids are highly effective in inducing quick remission in EoE and may be useful in the treatment of patients with fibrosis and severe symptoms (severe dysphagia, dehydration, weight loss, or esophageal strictures), they are hampered by several known adverse effects (e.g. weight gain, cushingoid manifestations), therefore the benefit-cost ratio should be discussed with 
Table $\mathbf{2}$ Characteristics of dietary approaches in the treatment of pediatric eosinophilic esophagitis

\begin{tabular}{|c|c|c|c|c|c|}
\hline $\begin{array}{l}\text { Dietary } \\
\text { approach }\end{array}$ & Definition & Indication & $\begin{array}{l}\text { Success } \\
\text { rate }\end{array}$ & Advantages & Disadvantages \\
\hline Elemental diet & $\begin{array}{l}\text { Diet consisting of amino acid-based } \\
\text { formula }\end{array}$ & $\begin{array}{l}\text { In patients with multiple allergies, growth } \\
\text { stop, severe disease unresponsive to } \\
\text { therapy or unable to follow a highly } \\
\text { restrictive diet }\end{array}$ & $90 \%$ & $\begin{array}{l}\text { Allergen-free } \\
\text { Nutritionally } \\
\text { complete }\end{array}$ & $\begin{array}{l}\text { Taste (feeding tube } \\
\text { could be needed) } \\
\text { Expensive } \\
\text { Age relevance } \\
\text { Elimination of all } \\
\text { foods } \\
\text { Negative impact on } \\
\text { the quality of life }\end{array}$ \\
\hline $\begin{array}{l}\text { Empiric } \\
\text { elimination diet } \\
\text { or six-food elim- } \\
\text { ination diet }\end{array}$ & $\begin{array}{l}\text { Elimination of "big six" major food } \\
\text { allergens from the diet (milk, egg, } \\
\text { wheat, soy, peanut/tree nut, and fish/ } \\
\text { shellfish) }\end{array}$ & $\begin{array}{l}\text { In the absence of specific allergic } \\
\text { sensitization to foods }\end{array}$ & $72 \%$ & $\begin{array}{l}\text { Allergy } \\
\text { testing not } \\
\text { needed }\end{array}$ & $\begin{array}{l}\text { Several eliminations } \\
\text { could be } \\
\text { unnecessary } \\
\text { Only four foods } \\
\text { may be essential } \\
\text { Expensive } \\
\text { Nutritional } \\
\text { deficiency }\end{array}$ \\
\hline Targeted diet & $\begin{array}{l}\text { Elimination of foods with a positive } \\
\text { response to allergy testing }\end{array}$ & $\begin{array}{l}\text { Strongly suspected food allergy based on } \\
\text { the clinical history and positive allergy } \\
\text { testing }\end{array}$ & $45-77 \%$ & $\begin{array}{l}\text { Food } \\
\text { specificity } \\
\text { Nutritional } \\
\text { preservation }\end{array}$ & $\begin{array}{l}\text { Different testing } \\
\text { precision and } \\
\text { technique among } \\
\text { centers } \\
\text { Low negative } \\
\text { predictive value of } \\
\text { milk testing } \\
\text { Unnecessary } \\
\text { avoidance if } \\
\text { sensitization } \\
\text { without clinical } \\
\text { allergy }\end{array}$ \\
\hline
\end{tabular}

the patient's family [131]. The most common topical steroids are represented by swallowed fluticasone propionate and oral viscous budesonide, which is an off-label use of anti-asthmatic medication [132, 133]. It is important to underline that patient should fast at least 30-60 min after treatment to reduce esophageal drug clearance. Budesonide orodispersible capsules approved for EoE are available for adults in some European countries (https://www.ema.europa.eu/en/documents/assessmentreport/jorveza-epar-public-assessment-report_en.pdf). In general, swallowed topical corticosteroids only have a few adverse effects, like esophageal candidiasis that is mostly asymptomatic and discovered during the endoscopy phase $[116,134]$. Fluconazole maybe used for treatment [116].

Swallowed steroids are used for long-term treatment, often indefinitely in the case of efficacy in controlling remission 8-12 weeks after initiating therapy. Attempts to reduce dosage may be made after 1-2 years of treatment followed by an endoscopy to demonstrate efficacy. Periodic rescopes are recommended even after remission as at times patients may become non-responsive to steroids [126].

Although adrenal insufficiency could be a side effect due to the use of prolonged high dose of steroids, the risk is negligible in patients with short-term topical corticosteroids ( $<12$ weeks) [135]. More attention to the adrenal axis should be considered in patients with concomitant use of additional topic steroids for comorbid allergic diseases (e.g asthma, atopic dermatitis, allergic rhinitis) $[135,136]$.

No evidence is now available regarding the potential role of topical steroids on growth impairment in patients with EoE [62]. In patients affected by asthma, a systematic review showed that regular use of inhaled corticosteroids (ICS) at low or medium daily dose is associated with reduction on linear growth that seems to be maximal during the first year of therapy and less pronounced behind the first year of treatment [137]. For that reason, as well as it is suggested to use the lowest effective dose of ICS in asthmatic patients, in the same way it is advisable for patients with EoE.

The different types of steroids are summarized in Table 1.

\section{Endoscopic therapy}

Endoscopic esophageal dilatation may be effective in case of rings or high-grade strictures (less than $10 \mathrm{~mm}$ ), or for the release of the bolus, especially when severe dysphagia is caused [138]. This approach which treats the fibrostenotic and structural alterations, shows good tolerance with long-lasting symptomatic relief. It should be considered in cases that are unresponsive to initial medical or diet therapy. Efforts are made to achieve an esophageal diameter of $16-17 \mathrm{~mm}$ aimed at preventing and treating food impactions. Although very infrequent, 
Table 3 Unmet needs in the management of pediatric eosinophilic esophagitis (modified from reference [62])

\begin{tabular}{ll}
\hline Diagnosis & Identify diagnostic and monitoring noninvasive biomarkers \\
& Increase the development of minimally invasive tools to acquire esophageal tissue \\
& Validate score to predict disease activity \\
Cross-reactivity between foods and airborne allergens & The timeframe of reintroduction: 6 versus 8 versus 12 weeks \\
Diet therapy & Predictive factors of food-elimination responsiveness \\
& Long-term response in adherent patients \\
& Dose and persistence of maintenance treatment (PPI and steroids) \\
Drug maintenance therapy & Safety of long-term minimum effective dose \\
& The predictive factor of steroid response and dependence \\
& Validation of current available biologic agents \\
Other therapy & Development of new agents targeting identified molecules \\
& Identification of possible new targets for biologic therapy \\
\hline
\end{tabular}

Legend: PPI proton-pump inhibitor

surgical esophagectomy is the extreme treatment option when complications occur.

\section{Other therapies}

Other drug treatments have been studied, such as leukotriene receptor antagonists (montelukast) [139], biologic agents (e.g., omalizumab, infliximab, mepolizumab, reslizumab) [140-144], immunomodulators (e.g., azathioprine, 6-mercaptopurine) [145] and oral viscous sodium cromoglicate [146], but without showing efficacy.

More promising are the data on biologics like dupilumab in treating EoE. Data from the first phase III trial of dupilumab, an antibody that inhibits the signaling of Il-4 and IL-13 proteins, highlighted how this drug changes the structural and histologic characters of EoE and decreases the patients' symptoms, such as the ability to swallow [147]. Hence, in September 2020, the FDA approved breakthrough investigational therapy with dupilumab for treating EoE in patients aged 12 years and older (https://www.globenewswire.com/news-release/202 0/09/14/2092666/0/en/FDA-grants-Dupixentdupilumab-Breakthrough-Therapy-designation-foreosinophilic-esophagitis.html), although it use in clinical practice has not yet been approved. Many other biologics are currently being studied for this disease [62].

\section{Conclusion}

Over recent decades, research progress has been made in terms of a greater understanding of the EoE pathogenesis, evaluation of less invasive diagnostic tools, and new therapeutic approaches.

However, there are still several unmet needs (Table 3), such as finding non-invasive diseasemonitoring methods and biomarkers for daily practice and the development of safe long-term maintenance therapy. Moreover, multidisciplinary management of
EoE is necessary, involving pediatricians, gastroenterologists, allergists, pathologists, and dietitians for the optimization of patient care.

\section{Authors' contributions}

E.N. and A.C. conceived the study, coordinated it, helped in drafting the manuscript and critically reviewed it. S.B., S.A., C.M. and L.P. articipated in the study's design, carried out the literature research and wrote the first draft of the manuscript. F.M., M.G., L.L., L.C., R.C., and F.S. reviewed and provided feedback. The author(s) read and approved the final manuscript.

\section{Competing interests}

The authors declare that they have no competing interests.

\section{Author details}

${ }^{1}$ Allergy Unit, Department of Pediatrics, Meyer Children's University Hospital, Florence, Italy. ${ }^{2}$ Predictive and Preventive Medicine Research Unit, Multifactorial and Systemic Diseases Research Area, Pediatric Allergy Unit, Bambino Gesù Children's Hospital IRCCS, Rome, Italy. ${ }^{3}$ Pediatric Unit and Emergency, University Hospital Consortium Corporation Polyclinic of Bari, Pediatric Hospital Giovanni XXIII, Bari, Italy. ${ }^{4}$ Department of Medicine and Surgery, University of Parma, Parma, Italy. ${ }^{5}$ Department of Medicine, University of Verona, Policlinico GB Rossi, Verona, Italy. ${ }^{6}$ Pediatric Unit, ASST Mantua, Mantua, Italy. ${ }^{7}$ Pediatric Unit, Senigallia Hospital, Senigallia, Italy.

${ }^{8}$ Pediatric Department, Latisana-Palmanova Hospital, Azienda Sanitaria Universitaria Friuli Centrale, Udine, Italy. 'Department of Pediatrics, Pediatric Clinic, Fondazione IRCCS Policlinico San Matteo, University of Pavia, Pavia, Italy. ${ }^{10}$ Department of Human Pathology in Adult and Development Age "Gaetano Barresi", Allergy Unit, Department of Pediatrics, AOU Policlinico Gaetano Martino, Messina, Italy. ${ }^{11}$ Pediatrics Department, Perelman School of Medicine, University of Pennsylvania, Philadelphia, USA. ${ }^{12}$ Allergy and Immunology Division, The Children's Hospital of Philadelphia, Philadelphia, USA.

Received: 29 January 2021 Accepted: 27 October 2021

Published online: 22 November 2021

\section{References}

1. Dellon ES, Hirano I. Epidemiology and natural history of eosinophilic esophagitis. Gastroenterology [Internet] WB Saunders. 2018;154:319-332.e3 Available from: https://linkinghub.elsevier.com/retrieve/pii/S00165085173 59711.

2. Straumann A, Simon H-U. Eosinophilic esophagitis: escalating epidemiology? J Allergy Clin Immunol [Internet]. 2005;115(2):418-9. Available from: https://linkinghub.elsevier.com/retrieve/pii/S009167490403 0441. https://doi.org/10.1016/j.jaci.2004.11.006. 
3. Prasad GA, Alexander JA, Schleck CD, Zinsmeister AR, Smyrk TC, Elias RM et al. Epidemiology of eosinophilic esophagitis over three decades in olmsted county, minnesota. Clin Gastroenterol Hepatol [Internet] Elsevier Inc. 2009;7:1055-61. https://doi.org/10.1016/j.cgh.2009.06.023.

4. van Rhijn BD, Verheij J, Smout AJPM, Bredenoord AJ. Rapidly increasing incidence of eosinophilic esophagitis in a large cohort. Neurogastroenterol Motil [Internet]. 2013;25(1):47-e5. https://doi.org/10.1111/nmo.12009.

5. Straumann A, Schoepfer A. Update on basic and clinical aspects of eosinophilic oesophagitis. Gut [Internet]. 2014;63(8):1355-63. https://doi. org/10.1136/gutjnl-2013-306414.

6. Friedlander JA, Deboer EM, Soden JS, Furuta GT, Menard-Katcher CD, Atkins D, et al. Unsedated transnasal esophagoscopy for monitoring therapy in pediatric eosinophilic esophagitis. Gastrointest Endosc [Internet] Elsevier, Inc. 2016;83:299-306.e1. https://doi.org/10.1016/j.gie.2015.05.044.

7. Alexander ES, Martin LJ, Collins MH, Kottyan LC, Sucharew $\mathrm{H}, \mathrm{He} H$, et al. Twin and family studies reveal strong environmental and weaker genetic cues explaining heritability of eosinophilic esophagitis. 2012;100:130-4.

8. Menard-Katcher C, Swerdlow MP, Mehta P, Furuta GT, Fenton LZ. Contribution of esophagram to the evaluation of complicated pediatric eosinophilic esophagitis. J Pediatr Gastroenterol Nutr. 2015;61(5):541-6. https://doi.org/10.1097/MPG.0000000000000849.

9. Gentile N, Katzka D, Ravi K, Trenkner S, Enders F, Killian J, et al. Oesophageal narrowing is common and frequently under-appreciated at endoscopy in patients with oesophageal eosinophilia. Aliment Pharmacol Ther. 2014; 40(11-12):1333-40. https://doi.org/10.1111/apt.12977.

10. Furuta GT, Kagalwalla AF, Lee JJ, Alumkal P, Maybruck BT, Fillon S, et al. The oesophageal string test: a novel, minimally invasive method measures mucosal inflammation in eosinophilic oesophagitis. Gut. 2013;62(10):1395405. https://doi.org/10.1136/gutjnl-2012-303171.

11. Katzka DA, Geno DM, Ravi A, Smyrk TC, Lao-Sirieix P, Miramedi A, et al. Accuracy, safety, and tolerability of tissue collection by cytosponge vs endoscopy for evaluation of eosinophilic esophagitis. Clin Gastroenterol Hepatol [Internet] Elsevier, Inc. 2015;13:77-83.e2. https://doi.org/10.1016/j.cgh.2014.06.026.

12. Tabatabaei N, Kang D, Wu T, Kim M, Carruth RW, Leung J, et al. Tethered confocal endomicroscopy capsule for diagnosis and monitoring of eosinophilic esophagitis. Biomed Opt Express [Internet]. 2014;5:197 Available from: https://www.osapublishing.org/boe/abstract.cfm?uri=boe-5-1-197.

13. González-Cervera J, Lucendo AJ. Eosinophilic esophagitis: an evidencebased approach to therapy. J Investig Allergol Clin Immunol. 2016;26(1):818. https://doi.org/10.18176/jiaci.0002.

14. Gonsalves N. Distinct features in the clinical presentations of eosinophilic esophagitis in children and adults: is this the same disease? Dig Dis. 2014; 32(1-2):89-92. https://doi.org/10.1159/000357078.

15. Landres RT, Kuster GGR, Strum WB. Eosinophilic esophagitis in a patient with vigorous achalasia. Gastroenterology [internet]. Elsevier Masson SAS. 1978;74(6):1298-301. https://doi.org/10.1016/0016-5085(78)90710-2.

16. Furuta GT, Liacouras CA, Collins MH, Gupta SK, Justinich C, Putnam PE, et al. Eosinophilic esophagitis in children and adults: a systematic review and consensus recommendations for diagnosis and treatment. Gastroenterol Int. 2007;133(4):1342-63. Available from: https://linkinghub.elsevier.com/retrieve/ pii/S0016508507014746. https://doi.org/10.1053/j.gastro.2007.08.017.

17. Dellon ES, Erichsen R, Baron JA, Shaheen NJ, Vyberg M, Sorensen HT, et al. The increasing incidence and prevalence of eosinophilic oesophagitis outpaces changes in endoscopic and biopsy practice: national populationbased estimates from Denmark. Aliment Pharmacol Ther. 2015;41(7):662-70. https://doi.org/10.1111/apt.13129.

18. Giriens B, Yan P, Safroneeva E, Zwahlen M, Reinhard A, Nydegger A, et al. Escalating incidence of eosinophilic esophagitis in Canton of Vaud, Switzerland, 1993-2013: a population-based study. Allergy [Internet]. 2015; 70:1633-9. https://doi.org/10.1111/all.12733.

19. Hruz P, Straumann A, Bussmann C, Heer P, Simon HU, Zwahlen M, et al. Escalating incidence of eosinophilic esophagitis: a 20-year prospective, population-based study in Olten County, Switzerland. J Allergy Clin Immunol [Internet] American Academy of Allergy, Asthma \& Immunology. 2011;128:1349-1350.e5. https://doi.org/10.1016/j.jaci.2011.09.013.

20. Dalby K, Nielsen RG, Kruse-Andersen S, Fenger C, Bindslev-Jensen C, Ljungberg $S$, et al. Eosinophilic Oesophagitis in infants and children in the region of southern Denmark: a prospective study of prevalence and clinical presentation. J Pediatr Gastroenterol Nutr [Internet]. 2010;51(3):280-2. Available from: https://journals.lww.com/00005176-201009000-00006. https://doi.org/10.1097/MPG.0b013e3181d1b107.
21. Licari A, Votto M, Scudeller L, De Silvestri A, Rebuffi C, Cianferoni A, et al. Epidemiology of nonesophageal eosinophilic gastrointestinal diseases in symptomatic patients: a systematic review and Meta-analysis. J allergy Clin Immunol Pract [internet] Elsevier Inc. 2020;8:1994-2003.e2. https://doi.org/1 0.1016/j.jaip.2020.01.060

22. Falk GW. Eosinophilic Esophagitis. Gastroenterol Clin North Am [Internet]. 2014;43:xiii Available from: https://linkinghub.elsevier.com/retrieve/pii/ S0889855314000387

23. Arias A, Pérez-Martínez I, Tenías JM, Lucendo AJ. Systematic review with meta-analysis: the incidence and prevalence of eosinophilic oesophagitis in children and adults in population-based studies. Aliment Pharmacol Ther. 2016;43(1):3-15. https://doi.org/10.1111/apt.13441.

24. Lyles J, Rothenberg M. Role of genetics, environment, and their interactions in the pathogenesis of eosinophilic esophagitis. Curr Opin Immunol [internet] Elsevier Itd. 2019;60:46-53. https://doi.org/10.1016/j.coi.2019.04.004.

25. Vinit C, Dieme A, Courbage S, Dehaine C, Dufeu CM, Jacquemot S, et al. Eosinophilic esophagitis: pathophysiology, diagnosis, and management. Arch Pédiatrie [internet] Elsevier Masson SAS. 2019;26:182-90. https://doi. org/10.1016/j.arcped.2019.02.005.

26. Votto M, Marseglia GL, De Filippo M, Brambilla I, Caimmi SME, Licari A. Early life risk factors in pediatric EoE: could we prevent this modern disease? Front Pediatr [Internet]. 2020a;8:1-10. https://doi.org/10.3389/fped.2020.002 63/full.

27. Sleiman PMA, Wang ML, Cianferoni A, Aceves S, Gonsalves N, Nadeau K, et al. GWAS identifies four novel eosinophilic esophagitis loci. Nat Commun [internet]. Nat Publ Group. 2014;5(1):1-5. https://doi.org/10.1038/ ncomms6593.

28. Kottyan LC, Parameswaran S, Weirauch MT, Rothenberg ME, Martin L. The genetic etiology of eosinophilic esophagitis. J allergy Clin Immunol [internet] Elsevier Inc. 2020;145:9-15. https://doi.org/10.1016/j.jaci.2019.11. 013.

29. O'Shea KM, Aceves SS, Dellon ES, Gupta SK, Spergel JM, Furuta GT, et al. Pathophysiology of eosinophilic esophagitis. Gastroenterology [internet] Elsevier, Inc. 2018;154:333-45. https://doi.org/10.1053/j.gastro.2017.06.065.

30. Kottyan LC, Rothenberg ME. Genetics of eosinophilic esophagitis. Mucosal Immunol [internet]. Nat Publ Group. 2017;10(3):580-8. https://doi.org/10.103 8/mi.2017.4

31. Sherrill JD, Gao PS, Stucke EM, Blanchard C, Collins MH, Putnam PE, et al. Variants of thymic stromal lymphopoietin and its receptor associate with eosinophilic esophagitis. J Allergy Clin Immunol [Internet] Elsevier Ltd. 2010; 126:160-165.e3. https://doi.org/10.1016/j.jaci.2010.04.037.

32. Dunn JLM, Shoda T, Caldwell JM, Wen T, Aceves SS, Collins MH, et al. Esophageal type 2 cytokine expression heterogeneity in eosinophilic esophagitis in a multisite cohort. J allergy Clin Immunol [internet] Elsevier Inc. 2020;145:1629-1640.e4. https://doi.org/10.1016/j.jaci.2020.01.051.

33. Blanchard C, Wang N, Stringer KF, Mishra A, Fulkerson PC, Abonia JP, et al. Eotaxin-3 and a uniquely conserved gene-expression profile in eosinophilic esophagitis. J Clin Invest. 2006;116(2):536-47. https://doi.org/10.1172/JCl2 6679 .

34. Litosh VA, Rochman M, Rymer JK, Porollo A, Kottyan LC, Rothenberg ME. Calpain-14 and its association with eosinophilic esophagitis. J Allergy Clin Immunol [Internet] Elsevier Inc. 2017;139:1762-1771.e7. https://doi.org/10.1 016/j.jaci.2016.09.027.

35. Rothenberg ME. Molecular, genetic, and cellular bases for treating eosinophilic esophagitis. Gastroenterology [internet] Elsevier Ltd. 2015; 148(6):1143-57. https://doi.org/10.1053/j.gastro.2015.02.002.

36. Clayton F, Peterson K. Eosinophilic esophagitis: pathophysiology and definition. Gastrointest Endosc Clin N am [internet] Elsevier Inc. 2018;28:114. https://doi.org/10.1016/j.giec.2017.07.011.

37. Davis BP, Rothenberg ME. Mechanisms of disease of eosinophilic esophagitis. Annu Rev Pathol Mech Dis. 2016;11(1):365-93. https://doi.org/1 0.1146/annurev-pathol-012615-044241.

38. O'Byrne PM, Inman MD, Parameswaran K. The trials and tribulations of IL-5, eosinophils, and allergic asthma. J Allergy Clin Immunol [Internet]. 2001; 108(4):503-8. Available from: https://linkinghub.elsevier.com/retrieve/pii/ S0091674901188020. https://doi.org/10.1067/mai.2001.119149.

39. Blanchard C, Mingler MK, McBride M, Putnam PE, Collins MH, Chang G, et al. Periostin facilitates eosinophil tissue infiltration in allergic lung and esophageal responses. Mucosal Immunol [Internet]. 2008;1(4):289-96. Available from: http://www.nature.com/articles/mi200815. https://doi.org/1 0.1038/mi.2008.15 
40. Wright BL, Nguyen N, Shim KP, Masterson JC, Jacobsen EA, Ochkur SI, Lee JJ, Furuta GT. Increased GATA-3 and T-bet expression in eosinophilic esophagitis versus gastroesophageal reflux disease. J Allergy Clin Immunol. 2018;141(5):1919-21.e5. https://doi.org/10.1016/j.jaci.2017.12.993.

41. Beppu LY, Anilkumar AA, Newbury RO, Dohil R, Broide DH, Aceves SS. TGFB1-induced phospholamban expression alters esophageal smooth muscle cell contraction in patients with eosinophilic esophagitis. J Allergy Clin Immunol [Internet] Elsevier Ltd. 2014;134:1100-1107.e4. https://doi.org/10.1 016/j.jaci.2014.04.004

42. Zuo L, Fulkerson PC, Finkelman FD, Mingler M, Fischetti CA, Blanchard C, et al. IL-13 induces esophageal remodeling and gene expression by an eosinophil-independent, IL-13Ra2-inhibited pathway. J Immunol. 2010; 185(1):660-9. https://doi.org/10.4049/jimmunol.1000471.

43. Wong CK, Hu S, Cheung PFY, Lam CWK. Thymic stromal lymphopoietin induces chemotactic and prosurvival effects in eosinophils: implications in allergic inflammation. Am J Respir Cell Mol Biol. 2010;43(3):305-15. https:// doi.org/10.1165/rcmb.2009-01680C

44. Allakhverdi Z, Comeau MR, Jessup HK, Yoon BRP, Brewer A, Chartier S, et al. Thymic stromal lymphopoietin is released by human epithelial cells in response to microbes, trauma, or inflammation and potently activates mast cells. J Exp Med. 2007;204(2):253-8. https://doi.org/10.1084/jem.20062211.

45. Noti M, Wojno EDT, Kim BS, Siracusa MC, Giacomin PR, Nair MG, et al. Thymic stromal lymphopoietin-elicited basophil responses promote eosinophilic esophagitis. Nat med [internet]. Nat Publ Group. 2013;19(8): 1005-13. https://doi.org/10.1038/nm.3281.

46. Jensen ET, Shah ND, Hoffman K, Sonnenberg A, Genta RM, Dellon ES. Seasonal variation in detection of oesophageal eosinophilia and eosinophilic oesophagitis. Aliment Pharmacol Ther [Internet]. 2015;42(4): 461-9. https://doi.org/10.1111/apt.13273.

47. Rayapudi M, Mavi P, Zhu X, Pandey AK, Abonia JP, Rothenberg ME, et al. Indoor insect allergens are potent inducers of experimental eosinophilic esophagitis in mice. J Leukoc Biol [Internet]. 2010;88(2):337-46. https://doi. org/10.1189/jlb.0110025.

48. Caldwell JM, Paul M, Rothenberg ME. Novel immunologic mechanisms in eosinophilic esophagitis. Curr Opin Immunol [internet]. Elsevier Ltd. 2017;48: 114-21. https://doi.org/10.1016/j.coi.2017.08.006.

49. Mishra A, Hogan SP, Brandt EB, Rothenberg ME. An etiological role for aeroallergens and eosinophils in experimental esophagitis. J Clin Invest. 2001;107(1):83-90. https://doi.org/10.1172/JCl10224.

50. Spergel JM, Beausoleil JL, Mascarenhas M, Liacouras CA. The use of skin prick tests and patch tests to identify causative foods in eosinophilic esophagitis. J Allergy Clin Immunol [Internet]. 2002;109(2):363-8. Available from: https://linkinghub.elsevier.com/retrieve/pii/S0091674902794670. https://doi.org/10.1067/mai.2002.121458

51. Ruffner MA, Capucilli P, Hill DA, Spergel JM. Screening children for eosinophilic esophagitis: allergic and other risk factors. Expert rev Clin Immunol [internet] Taylor \& Francis. 2019;15:315-8. https://doi.org/10.1080/1 744666X.2019.1579643.

52. Hill DA, Dudley JW, Spergel JM. The prevalence of eosinophilic esophagitis in pediatric patients with IgE-mediated food allergy. J Allergy Clin Immunol Pract. 2017;5(2):369-75. https://doi.org/10.1016/j.jaip.2016.11.020.

53. Cianferoni A. Eosinophilic esophagitis as a side effect of food oral immunotherapy. Med. 2020;56:1-12.

54. Krupp NL, Sehra S, Slaven JE, Kaplan MH, Gupta S, Tepper RS. Increased prevalence of airway reactivity in children with eosinophilic esophagitis. Pediatr Pulmonol. 2016;51(5):478-83. https://doi.org/10.1002/ppul.23327.

55. Jensen ET, Kuhl JT, Martin LJ, Langefeld CD, Dellon ES, Rothenberg ME. Early-life environmental exposures interact with genetic susceptibility variants in pediatric patients with eosinophilic esophagitis. J Allergy Clin Immunol [Internet] Elsevier Inc. 2018;141:632-637.e5. https://doi.org/10.101 6/j.jaci.2017.07.010.

56. Jensen ET, Bertelsen RJ. Assessing early life factors for eosinophilic esophagitis: lessons from other allergic diseases. Curr Treat Options Gastroenterol. 2016;14(1):39-50. https://doi.org/10.1007/s11938-016-0083-1.

57. Dellon ES, Peery AF, Shaheen NJ, Morgan DR, Hurrell JM, Lash RH, et al. Inverse association of esophageal eosinophilia with Helicobacter pylori based on analysis of a US pathology database. Gastroenterology [Internet] Elsevier Inc. 2011;141:1586-92. https://doi.org/10.1053/j.gastro.2011.06.081.

58. Chen JW, Kao JY. Eosinophilic esophagitis: update on management and controversies. BMJ [Internet]. 2017;359:j4482. https://doi.org/10.1136/bmj.j4482.
59. Ryu S, Lee KH, Tizaoui K, Terrazzino S, Cargnin S, Effenberger M, et al. Pathogenesis of eosinophilic esophagitis: a comprehensive review of the genetic and molecular aspects. Int J Mol Sci. 2020;21(19):1-20. https://doi. org/10.3390/ijms21197253.

60. Furuta GT, Katzka DA. Eosinophilic Esophagitis. Ingelfinger JR, editor. N Engl J Med [Internet]. 2015;373:1640-1648. https://doi.org/10.1056/NEJMra1502863

61. Spergel JM, Brown-Whitehorn TA, Muir A, Liacouras CA. Medical algorithm: diagnosis and treatment of eosinophilic esophagitis in children. Allergy [Internet]. 2020;75(6):1522-4. https://doi.org/10.1111/all.14188.

62. Rossetti D, Isoldi S, Oliva S. Eosinophilic esophagitis: update on diagnosis and treatment in pediatric patients. Pediatr drugs [internet] Springer international publishing. 2020;22:343-56. https://doi.org/10.1007/s40272-02 0-00398-z.

63. Muir AB, Brown-Whitehorn T, Godwin B, Cianferoni A. Eosinophilic esophagitis: early diagnosis is the key. Clin Exp Gastroenterol [Internet]. 2019;12:391-9. Available from: https://www.dovepress.com/eosinophilicesophagitis-early-diagnosis-is-the-key-peer-reviewed-article-CEG. https://doi. org/10.2147/CEG.S175061.

64. Whelan KA, Godwin BC, Wilkins B, Elci OU, Benitez A, DeMarshall M, et al. Persistent basal cell hyperplasia is associated with clinical and endoscopic findings in patients with histologically inactive eosinophilic esophagitis. Clin Gastroenterol Hepatol [Internet]. 2020;18:1475-1482.e1 Available from: https://linkinghub.elsevier.com/retrieve/pii/S1542356519309772.

65. Kasagi Y, Dods K, Wang JX, Chandramouleeswaran PM, Benitez AJ, Gambanga F, et al. Fibrostenotic eosinophilic esophagitis might reflect epithelial lysyl oxidase induction by fibroblast-derived TNF-a. J allergy Clin Immunol [internet] Elsevier Inc. 2019;144:171-82. https://doi.org/10.1016/j.ja ci.2018.10.067.

66. Gomez Torrijos E, Gonzalez-Mendiola R, Alvarado M, Avila R, PrietoGarcia A, Valbuena T, et al. Eosinophilic Esophagitis: Review and Update. Front Med [Internet] Frontiers Media SA. 2018;5. https://doi. org/10.3389/fmed.2018.00247/full.

67. Votto M, Castagnoli R, De Filippo M, Brambilla I, Cuppari C, Marseglia GL, Licari A. Behavioral issues and quality of life in children with eosinophilic esophagitis. Minerva Pediatr. 2020;72(5):424-32. https://doi.org/10.23736/ S0026-4946.20.05913-7.

68. Lucendo AJ, Sánchez-Cazalilla M. Adult versus pediatric eosinophilic esophagitis: important differences and similarities for the clinician to understand. Expert Rev Clin Immunol. 2012;8(8):733-45. https://doi.org/10.1 586/eci.12.68.

69. Liacouras CA, Furuta GT, Hirano I, Atkins D, Attwood SE, Bonis PA, et al. Eosinophilic esophagitis: Updated consensus recommendations for children and adults. J Allergy Clin Immunol [Internet] Mosby Inc. 2011; 128:3-20.e6 Available from: https://linkinghub.elsevier.com/retrieve/pii/ S0091674911003733.

70. Schoepfer AM, Safroneeva E, Bussmann C, Kuchen T, Portmann S, Simon $\mathrm{H}$, et al. Delay in diagnosis of eosinophilic esophagitis increases risk for stricture formation in a time-dependent manner. Gastroenterology [Internet] Elsevier Ltd. 2013;145:1230-1236.e2. https:// doi.org/10.1053/j.gastro.2013.08.015.

71. Orenstein SR, Shalaby TM, Di Lorenzo C, Putnam PE, Sigurdsson L, Kocoshis SA. The spectrum of pediatric eosinophilic esophagitis beyond infancy: a clinical series of 30 children. Am J Gastroenterol. 2000;95(6):1422-30. https:// doi.org/10.1111/j.1572-0241.2000.02073.x.

72. Rubinstein $E$, Rosen RL. Respiratory symptoms associated with eosinophilic esophagitis. Pediatr Pulmonol. 2018;53(11):1587-91. https://doi.org/10.1002/ ppul.24168.

73. Kelly EA, Linn D, Keppel KL, Noel RJ, Chun RH. Otolaryngologic surgeries are frequent in children with eosinophilic esophagitis. Ann Otol Rhinol Laryngol [Internet]. 2015;124(5):355-60. https://doi.org/10.1177/0003489414558108.

74. Dauer EH, Ponikau JU, Smyrk TC, Murray JA, Thompson DM. Airway manifestations of pediatric eosinophilic esophagitis: a clinical and histopathologic report of an emerging association. Ann Otol Rhinol Laryngol [Internet]. 2006;115(7):507-17. https://doi.org/10.1177/00034894 0611500705.

75. Orizio P, Cinquini M, Minetti S, Alberti D, Di Paolo C, Villanacci V, et al. Chronic cough and eosinophilic esophagitis: an uncommon association. Case Rep Gastroenterol. 2011;5(2):497-501. https://doi.org/10.1159/000331510.

76. Dellon ES, Jensen ET, Martin CF, Shaheen NJ, Kappelman MD. Prevalence of Eosinophilic Esophagitis in the United States. Clin Gastroenterol Hepatol 
[Internet] Elsevier, Inc. 2014;12:589-596.e1. https://doi.org/10.1016/j.cgh.2 013.09.008.

77. Waibel KH. 14 years of eosinophilic esophagitis: clinical features and prognosis. Pediatrics. 2009;124(Supplement 2):30-6. https://doi.org/10.1542/ peds.2009-1870DD.

78. Assa'ad AH, Putnam PE, Collins MH, Akers RM, Jameson SC, Kirby CL, et al. Pediatric patients with eosinophilic esophagitis: an 8-year follow-up. J Allergy Clin Immunol [Internet]. 2007;119(3):731-8. Available from: https:// linkinghub.elsevier.com/retrieve/pii/S0091674906037924. https://doi.org/10.1 016/j.jaci.2006.10.044.

79. Guajardo JR, Plotnick LM, Fende JM, Collins MH, Putnam PE, Rothenberg ME. Eosinophil-associated gastrointestinal disorders: A world-wide-web based registry. J Pediatr [Internet]. 2002;141:576-81 Available from: https:// linkinghub.elsevier.com/retrieve/pii/S0022347602001452.

80. Sugnanam KKN, Collins JT, Smith PK, Connor F, Lewindon P, Cleghorn G, et al. Dichotomy of food and inhalant allergen sensitization in eosinophilic esophagitis. Allergy Eur J Allergy Clin Immunol. 2007;62(11):1257-60. https:// doi.org/10.1111/j.1398-9995.2007.01454.x.

81. Talathi S, Knight T, Dimmitt R, Mestre J, Jester T. Concurrent eosinophilic esophagitis in pediatric patients with inflammatory bowel disease. Ann Allergy, Asthma Immunol [Internet]. 2019;123:313-6 Available from: https:// linkinghub.elsevier.com/retrieve/pii/S1081120619304545.

82. Abonia JP, Wen T, Stucke EM, Grotjan T, Griffith MS, Kemme KA, et al. High prevalence of eosinophilic esophagitis in patients with inherited connective tissue disorders. J Allergy Clin Immunol [internet] Elsevier Ltd. 2013;132(2): 378-86. https://doi.org/10.1016/j.jaci.2013.02.030.

83. Capucilli P, Cianferoni A, Grundmeier RW, Spergel JM. Comparison of comorbid diagnoses in children with and without eosinophilic esophagitis in a large population. Ann Allergy Asthma Immunol [internet] Elsevier Inc. 2018;121:711-6. https://doi.org/10.1016/j.anai.2018.08.022.

84. Peterson K, Firszt R, Fang J, Wong J, Smith KR, Brady KA. Risk of autoimmunity in EoE and families: a population-based cohort study. Am J Gastroenterol [internet]. Nat Publ Group. 2016;111(7):926-32. https://doi. org/10.1038/ajg.2016.185

85. Kottyan L, Spergel JM, Cianferoni A. Immunology of the ancestral differences in eosinophilic esophagitis. Ann Allergy Asthma Immunol [internet]. American College of Allergy, Asthma \& Immunology. 2019;122: 443-4. https://doi.org/10.1016/j.anai.2018.10.026.

86. Ruffner MA, Cianferoni A. Phenotypes and endotypes in eosinophilic esophagitis. Ann Allergy Asthma Immunol [internet] American College of Allergy, Asthma \& Immunology. 2020;124:233-9. https://doi.org/10.1016/j.a nai.2019.12.011.

87. Dellon ES, Liacouras CA, Molina-Infante J, Furuta GT, Spergel JM, Zevit N, et al. Updated international consensus diagnostic criteria for eosinophilic esophagitis: proceedings of the AGREE conference. Gastroenterology [internet] Elsevier, Inc. 2018;155:1022-1033.e10. https://doi.org/10.1053/j.ga stro.2018.07.009.

88. Dellon ES, Gonsalves N, Hirano I, Furuta GT, Liacouras CA, Katzka DA. ACG clinical guideline: evidenced based approach to the diagnosis and Management of Esophageal Eosinophilia and Eosinophilic Esophagitis (EoE). Am J Gastroenterol [internet] Nat Publ Group. 2013;108(5):679-92. https:// doi.org/10.1038/ajg.2013.71.

89. Cheng E, Zhang X, Huo X, Yu C, Zhang Q, Wang DH, et al. Omeprazole blocks eotaxin-3 expression by oesophageal squamous cells from patients with eosinophilic oesophagitis and GORD. Gut [Internet]. 2013;62(6):824-32. https://doi.org/10.1136/gutjnl-2012-302250.

90. Zhang X, Cheng E, Huo X, Yu C, Zhang Q, Pham TH, et al. Omeprazole blocks STAT6 binding to the Eotaxin-3 promoter in eosinophilic esophagitis cells. PLoS One. 2012;7(11). https://doi.org/10.1371/journal. pone.0050037.

91. Kim HP, Vance RB, Shaheen NJ, Dellon ES. The prevalence and diagnostic utility of endoscopic features of eosinophilic esophagitis: a meta-analysis. Clin Gastroenterol Hepatol [Internet] Elsevier Inc. 2012;10:988-996.e5. https://doi.org/10.1016/j.cgh.2012.04.019.

92. Hirano I, Moy N, Heckman MG, Thomas CS, Gonsalves N, Achem SR. Endoscopic assessment of the oesophageal features of eosinophilic oesophagitis: validation of a novel classification and grading system. Gut [Internet]. 2013;62(4):489-95. https://doi.org/10.1136/gutjnl-2011-3 01817.

93. Collins MH, Martin LJ, Alexander ES, Todd Boyd J, Sheridan R, He H, et al. Newly developed and validated eosinophilic esophagitis histology scoring system and evidence that it outperforms peak eosinophil count for disease diagnosis and monitoring. Dis Esophagus. 2017;30(3):1-8. https://doi.org/1 $0.1111 /$ dote. 12470 .

94. Dellon ES, Gibbs WB, Fritchie KJ, Rubinas TC, Wilson LA, Woosley JT, et al. Clinical, endoscopic, and histologic findings distinguish eosinophilic esophagitis from gastroesophageal reflux disease. Clin Gastroenterol Hepatol [Internet] Elsevier Inc. 2009;7:1305-13. https://doi.org/10.1016/j. cgh.2009.08.030.

95. Votto M, De Filippo M, Caminiti L, Carella F, de Castro G, Landi M, et al. Eosinophilic gastrointestinal disorders and allergen immunotherapy: lights and shadows. Pediatr Allergy Immunol Pediatr Allergy Immunol. 2021;32(5): 814-23. https://doi.org/10.1111/pai.13458.

96. Miehlke S, Alpan O, Schröder S, Straumann A. Induction of eosinophilic esophagitis by sublingual pollen immunotherapy. Case Rep Gastroenterol. 2013;7(3):363-8. https://doi.org/10.1159/000355161.

97. Egan M, Atkins D. What Is the Relationship Between Eosinophilic Esophagitis (EoE) and Aeroallergens? Implications for Allergen Immunotherapy. Curr Allergy Asthma Rep [Internet] Curr Allergy Asthma Rep. 2018;18(8):43. https://doi.org/10.1007/s11882-018-0798-2.

98. Rokosz M, Bauer C, Schroeder S. Eosinophilic esophagitis induced by aeroallergen sublingual immunotherapy in an enteral feeding tubedependent pediatric patient. Ann Allergy, Asthma Immunol [Internet] American College of Allergy, Asthma \& Immunology. 2017;119:88-9. https:// doi.org/10.1016/j.anai.2017.05.004.

99. Derderian CA, Szmuk P, Derderian CK. Behind the black box. Plast Reconstr Surg [Internet]. 2017;140(4):787-92. Available from: http://journals.lww.com/ 00006534-201710000-00028. https://doi.org/10.1097/PRS.0000000000003691.

100. Soriano SG, McCann ME. Is anesthesia bad for the brain? Current knowledge on the impact of anesthetics on the developing brain. Anesthesiol Clin. 2020;38(3):477-92. https://doi.org/10.1016/.anclin.2020.05.007.

101. Hines BT, Rank MA, Wright BL, Marks LA, Hagan JB, Straumann A, et al. Minimally invasive biomarker studies in eosinophilic esophagitis: a systematic review. Ann Allergy Asthma Immunol [internet] Elsevier Inc. 2018; 121:218-28. https://doi.org/10.1016/j.anai.2018.05.005.

102. Benitez AJ, Hoffmann C, Muir AB, Dods KK, Spergel JM, Bushman FD, et al. Inflammation-associated microbiota in pediatric eosinophilic esophagitis. Microbiome [Internet]. 2015;3:23 Available from: ???

103. Hiremath G, Shilts MH, Boone HH, Correa H, Acra S, Tovchigrechko A, et al. The salivary microbiome is altered in children with eosinophilic esophagitis and correlates with disease activity. Clin Transl Gastroenterol. 2019;10(6):1-9. https://doi.org/10.14309/ctg.0000000000000039.

104. Johnson K, Iyer V, Katzka D, Ravi K, Lennon R, Pendegraft R, et al. Poor relationship between fractionated exhaled nitric oxide and disease activity in eosinophilic esophagitis. Dysphagia [internet] Springer US. 2019;34:13844. https://doi.org/10.1007/s00455-018-9925-4.

105. Fox VL, Nurko S, Teitelbaum JE, Badizadegan K, Furuta GT. High-resolution EUS in children with eosinophilic "allergic" esophagitis. Gastrointest Endosc. 2003;57(1):30-6. https://doi.org/10.1067/mge.2003.33.

106. Straumann A, Conus S, Degen L, Frei C, Bussmann C, Beglinger C, et al. Long-term budesonide maintenance treatment is partially effective for patients with eosinophilic esophagitis. Clin Gastroenterol Hepatol [Internet] Elsevier Inc. 2011;9:400-409.e1. https://doi.org/10.1016/j.cgh.2011.01.017.

107. Carlson DA, Hirano I, Zalewski A, Gonsalves N, Lin Z, Pandolfino JE. Improvement in esophageal Distensibility in response to medical and diet therapy in eosinophilic esophagitis. Clin Transl Gastroenterol [internet] Nat Publ Group. 2017;8(10):e119-8. https://doi.org/10.1038/ctg.2017.47.

108. Patel DA, Higginbotham T, Slaughter JC, Aslam M, Yuksel E, Katzka D, et al. Development and Validation of a Mucosal Impedance Contour Analysis System to Distinguish Esophageal Disorders. Gastroenterology. 2019;156: 1617-1626.e1.

109. Han ES. Goleman, Daniel; boyatzis, Richard; Mckee a. 济無no title No title. J Chem Inf Model. 2019;53:1689-99.

110. Protheroe C, Woodruff SA, de Petris G, Mukkada V, Ochkur SI, Janarthanan S, et al. A novel histologic scoring system to evaluate mucosal biopsies from patients with eosinophilic esophagitis. Clin Gastroenterol Hepatol [Internet] AGA Institute. 2009;7:749-755.e11. https://doi.org/10.1016/j.cgh.2009.03.022.

111. Shoda T, Wen T, Aceves SS, Abonia JP, Atkins D, Bonis PA, et al. Eosinophilic oesophagitis endotype classification by molecular, clinical, and histopathological analyses: a cross-sectional study. Lancet Gastroenterol Hepatol [internet] Elsevier Ltd. 2018;3(7):477-88. https://doi.org/10.1016/S24 68-1253(18)30096-7. 
112. Cianferoni A, Shuker M, Brown-Whitehorn T, Hunter H, Venter C, Spergel JM. Food avoidance strategies in eosinophilic oesophagitis. Clin Exp Allergy. 2019a;49(3):269-84. https://doi.org/10.1111/cea.13360.

113. Munoz-Persy M, Lucendo AJ. Treatment of eosinophilic esophagitis in the pediatric patient: an evidence-based approach. Eur J Pediatr [Internet]. 2018; 177(5):649-63. https://doi.org/10.1007/s00431-018-3129-7.

114. Gonsalves NP, Aceves SS. Diagnosis and treatment of eosinophilic esophagitis. J allergy Clin Immunol [internet] Elsevier Inc. 2020;145:1-7. https://doi.org/10.1016/j.jaci.2019.11.011.

115. Greuter T, Straumann A. Medical algorithm: diagnosis and treatment of eosinophilic esophagitis in adults. Allergy [Internet]. 2020;75(3):727-30. https://doi.org/10.1111/all.14112.

116. Lucendo AJ, Molina-Infante J, Arias Á, von Arnim U, Bredenoord AJ, Bussmann C, et al. Guidelines on eosinophilic esophagitis: evidence-based statements and recommendations for diagnosis and management in children and adults. United European Gastroenterol J. 2017;5(3):335-58. https://doi.org/10.1177/2050640616689525.

117. Ruffner MA, Spergel JM. Eosinophilic Esophagitis in Children. Curr Allergy Asthma Rep [Internet] Current Medicine Group LLC 1. 2017a;17:54. https:// doi.org/10.1007/s11882-017-0721-2.

118. Eusebi LH, Rabitti S, Artesiani ML, Gelli D, Montagnani M, Zagari RM, et al. Proton pump inhibitors: risks of long-term use. J Gastroenterol Hepatol. 2017;32(7):1295-302. https://doi.org/10.1111/jgh.13737.

119. De Bruyne $P$, Ito $S$. Toxicity of long-term use of proton pump inhibitors in children. Arch Dis Child. 2018;103(1):78-82. https://doi.org/10.1136/a rchdischild-2017-314026.

120. Bashaw H, Schwartz S, Kagalwalla AF, Wechsler JB. Tutorial: nutrition therapy in eosinophilic esophagitis—outcomes and deficiencies. J Parenter Enter Nutr [Internet]. 2020;44(4):600-9. https://doi.org/10.1002/jpen.1738.

121. Cianferoni A, Shuker M, Brown-Whitehorn T, Hunter H, Venter C, Spergel JM. Food avoidance strategies in eosinophilic oesophagitis. Clin Exp Allergy [Internet]. 2019b;49(3):269-84. https://doi.org/10.1111/cea.13360.

122. Arias Á, González-Cervera J, Tenias JM, Lucendo AJ. Efficacy of dietary interventions for inducing histologic remission in patients with eosinophilic esophagitis: a systematic review and Meta-analysis. Gastroenterology [internet] Elsevier, Inc. 2014;146(7):1639-48. https://doi.org/10.1053/j.gastro.2014.02.006.

123. Kelly KJ, Lazenby AJ, Rowe PC, Yardley JH, Perman JA, Sampson HA. Eosinophilic esophagitis attributed to gastroesophageal reflux: improvement with an amino acid-based formula. Gastroenterology. 1995;109(5):1503-12. https://doi.org/10.1016/0016-5085(95)90637-1.

124. Liacouras CA, Spergel JM, Ruchelli E, Verma R, Mascarenhas M, Semeao E, et al. Eosinophilic esophagitis: a 10-year experience in 381 children. 2005.

125. Markowitz JE, Clayton SB. Eosinophilic esophagitis in children and adults. Gastrointest Endosc Clin N am [internet] Elsevier Inc. 2018;28:59-75. https:// doi.org/10.1016/j.giec.2017.07.004.

126. Papadopoulou A, Koletzko S, Heuschkel R, Dias JA, Allen KJ, Murch SH, et al. Management guidelines of eosinophilic esophagitis in childhood. J Pediatr Gastroenterol Nutr [Internet]. 2014;58(1):107-18. Available from: https:// journals.lww.com/00005176-201401000-00027. https://doi.org/10.1097/MPG. Ob013e3182a80be1.

127. Votto M, De Filippo M, Olivero F, Raffaele A, Cereda E, De Amici M, et al. Malnutrition in eosinophilic gastrointestinal disorders. Nutrients [Internet]. 2020b;13:128 Available from: https://www.mdpi.com/2072-6643/13/1/128.

128. Kagalwalla AF, Sentongo TA, Ritz S, Hess T, Nelson SP, Emerick KM, et al. Effect of six-food elimination diet on clinical and histologic outcomes in eosinophilic esophagitis. Clin Gastroenterol Hepatol [Internet]. 2006;4(9): 1097-102. Available from: https://linkinghub.elsevier.com/retrieve/pii/S15423 56506004952. https://doi.org/10.1016/j.cgh.2006.05.026.

129. Rank MA, Sharaf RN, Furuta GT, Aceves SS, Greenhawt M, Spergel JM, et al. Technical review on the management of eosinophilic esophagitis: a report from the AGA institute and the joint task force on allergy-immunology practice parameters. Ann Allergy, Asthma Immunol [Internet] Elsevier. 2020; 124:424-440.e17. https://doi.org/10.1016/j.anai.2020.03.021.

130. Spergel JM, Brown-Whitehorn TF, Cianferoni A, Shuker M, Wang M-L, Verma $R$, et al. Identification of causative foods in children with eosinophilic esophagitis treated with an elimination diet. J Allergy Clin Immunol [Internet] Mosby Inc. 2012a;130:461-467.e5 Available from: https:// linkinghub.elsevier.com/retrieve/pii/S0091674912008597.

131. Ruffner MA, Spergel JM. Eosinophilic Esophagitis in Children. Curr Allergy Asthma Rep [Internet]. 2017b;17(8):54. https://doi.org/10.1007/s11882-0170721-2.
132. Aceves SS, Bastian JF, Newbury RO, Dohil R. Oral viscous budesonide: a potential new therapy for eosinophilic esophagitis in children. Am J Gastroenterol. 2007;102(10):2271-9. https://doi.org/10.1111/j.1572-0241.2007. 01379.x.

133. Dohil R, Newbury R, Fox L, Bastian J, Aceves S. Oral viscous budesonide is effective in children with eosinophilic esophagitis in a randomized, placebocontrolled trial. Gastroenterology [Internet] Elsevier Inc. 2010;139:418-429.e1. https://doi.org/10.1053/j.gastro.2010.05.001.

134. Benitez AJ, Tanes C, Mattei L, Hofstaedter CE, Kim DK, Gross J, et al. Effect of topical swallowed steroids on the bacterial and fungal esophageal microbiota in eosinophilic esophagitis. Allergy [Internet]. 2021;76:1549-52. https://doi.org/10.1111/all.14602.

135. Hsu S, Wood C, Pan Z, Rahat H, Zeitler P, Fleischer D, et al. Adrenal insufficiency in pediatric eosinophilic esophagitis patients treated with swallowed topical steroids. Pediatr Allergy Immunol Pulmonol. 2017;30(3): 135-40. https://doi.org/10.1089/ped.2017.0779.

136. Philpott H, Dougherty MK, Reed CC, Caldwell M, Kirk D, Torpy DJ, et al. Systematic review: adrenal insufficiency secondary to swallowed topical corticosteroids in eosinophilic oesophagitis. Aliment Pharmacol Ther [Internet]. 2018;47:1071-8. https://doi.org/10.1111/apt.14573.

137. MacEdo MS. The effects on growth of inhaled corticosteroids in children with persistent asthma. Am J Nurs. 2015;115(6):21. https://doi.org/10.1097/ 01.NAJ.0000466309.16014.9e.

138. Akhondi H. Diagnostic approaches and treatment of eosinophilic esophagitis. A review article. Ann med Surg [internet] Elsevier Ltd. 2017;20: 69-73. https://doi.org/10.1016/j.amsu.2017.06.022.

139. Alexander JA, Ravi K, Enders FT, Geno DM, Kryzer LA, Mara KC, et al. Montelukast does not maintain symptom remission after topical steroid therapy for eosinophilic esophagitis. Clin Gastroenterol Hepatol [Internet] Elsevier Ltd. 2017;15:214-221.e2. https://doi.org/10.1016/j.cgh.2016.09.013.

140. Clayton F, Fang JC, Gleich GJ, Lucendo AJ, Olalla JM, Vinson LA, et al. Eosinophilic esophagitis in adults is associated with IgG4 and not mediated by lgE. Gastroenterology [internet] Elsevier Ltd. 2014;147(3):602-9. https:// doi.org/10.1053/j.gastro.2014.05.036.

141. Assa'ad AH, Gupta SK, Collins MH, Thomson M, Heath AT, Smith DA, et al. An antibody against IL-5 reduces numbers of esophageal intraepithelial eosinophils in children with eosinophilic esophagitis. Gastroenterology [Internet] Elsevier Inc. 2011;141:1593-604. https://doi.org/10.1053/j.gastro.2 011.07.044.

142. Straumann A, Conus S, Grzonka P, Kita H, Kephart G, Bussmann C, et al. Anti-interleukin-5 antibody treatment (mepolizumab) in active eosinophilic oesophagitis: a randomised, placebo-controlled, double-blind trial. Gut. 2010;59(01):21-30. https://doi.org/10.1136/gut.2009.178558.

143. Markowitz JE, Jobe L, Miller M, Frost C, Laney Z, Eke R. Safety and efficacy of Reslizumab for children and adolescents with eosinophilic esophagitis treated for 9 years. J Pediatr Gastroenterol Nutr. 2018;66(6):893-7. https:// doi.org/10.1097/MPG.0000000000001840.

144. Spergel JM, Rothenberg ME, Collins MH, Furuta GT, Markowitz JE, Fuchs G, et al. Reslizumab in children and adolescents with eosinophilic esophagitis: Results of a double-blind, randomized, placebo-controlled trial. J Allergy Clin Immunol [Internet] Elsevier Ltd. 2012b;129:456-463.e3. https://doi.org/10.101 6/j.jaci.2011.11.044.

145. Netzer P, Gschossmann JM, Straumann A, Sendensky A, Weimann R, Schoepfer AM. Corticosteroid-dependent eosinophilic oesophagitis: azathioprine and 6-mercaptopurine can induce and maintain long-term remission. Eur J Gastroenterol Hepatol. 2007;19(10):865-9. https://doi.org/1 0.1097/MEG.0b013e32825a6ab4.

146. Lieberman JA, Zhang J, Whitworth J, Cavender C. A randomized, doubleblinded, placebo-controlled study of the use of viscous oral cromolyn sodium for the treatment of eosinophilic esophagitis. Ann Allergy Asthma Immunol [internet] Elsevier Inc. 2018;120:527-31. https://doi.org/10.1016/j.a nai.2018.03.006.

147. Wechsler JB, Hirano I. Biological therapies for eosinophilic gastrointestinal diseases. J allergy Clin Immunol [internet] Elsevier Inc. 2018;142:24-31.e2. https://doi.org/10.1016/j.jaci.2018.05.018.

\section{Publisher's Note}

Springer Nature remains neutral with regard to jurisdictional claims in published maps and institutional affiliations. 